\title{
Effect of spray dryer settings on the morphology of illite clay granules
}

\author{
A.Stunda-Zujeva, V.Stepanova, L.Bērziņa-Cimdiṇa \\ Riga Technical University Institute of General Chemical Engineering, \\ P.Valdena Street 3, Riga, Latvia, e-mail of corresponding author: \\ agnese.stunda-zujeva@rtu.lv
}

\begin{abstract}
Spray drying is an effective and common method for powder drying, e.g. clay. The morphology and properties of spray dried granules depend on properties of slurry and operational conditions of spray dryer. The aim of this study was to investigate the effect of spray dryer settings on the morphology of illite clay granules.

Laboratory scale spray dryer was used. Operational conditions: inlet temperature $190-220^{\circ} \mathrm{C}$, outlet temperature 70-96 ${ }^{\circ} \mathrm{C}$, spray dispersion is obtained using two-fluid nozzle where the slurry feed was varied from $4.5 \mathrm{to} 15 \mathrm{ml} / \mathrm{min}$ and gas pressure $15-40 \mathrm{~mm}$. Slurry was prepared from clay fraction under $2 \mu \mathrm{m}$ without additives. Latvian illite clay from Iecava, Pavāri and Laža deposits was studied. Slurries with concentration 1, 8 and 15 mass\% was used. The size and morphology was investigated by scanning electron microscopy, surface area and porosity by liquid nitrogen sorption.

All obtained granules irrespective of spray dryer settings were well-rounded and dense without large pores or holes, however the surface was rough. The mean diameter of granules was in range of 2.6-5.4 $\mu \mathrm{m}$, depending on slurry feed rate. The surface area of produced granules mostly depended on clay composition and was in a range of 70-92 $\mathrm{m} 2 / \mathrm{g}$. Inlet temperature in a range of $190-220{ }^{\circ} \mathrm{C}$ was found to be appropriate to produce well dried clay granules (moisture content $<10 \mathrm{wt} \%$ ).
\end{abstract}

Keywords: clay, illite, Latvian clay powder, spray-drying, slurry.

\section{INTRODUCTION}

Spray-drying is a convenient process for producing a granulated powder. It is an effective and fast method for slurry drying because of large surface area of sprayed droplets. The advantages of spray dried clays are uniform particle size [1] and randomly oriented particles in each granule and therefore in obtained powder. This is important e.g. in mineral analysis by X-ray diffraction [2]. The only disadvantage is mass losses due to small particles flying away with air flow. Conversion of fine powder to coarser makes the material less dusty that is safer for workers and makes easier to handle the material.

The most widespread clay mineral in Latvia is illite. The common use of illite clays is in building materials and pottery. However, it is worth to look for new applications, for example, as fillers in some composite materials or toners and thickeners in slurries, e.g. in cosmetics [3], in waste water purification from admixtures of organic dyes [4] and industrial waste treatment [5]. The influence of mineralogical composition, electrical conductivity and $\mathrm{pH}$ on the rheological properties of Latvian illite clays is described elsewhere [6], it was found that viscosity and plasticity can be influenced even by small differences between mineralogical compositions of sample.

The morphology and properties of spray dried granules depends on slurry properties (e.g. surface tension, viscosity, density) and operational conditions of spray dryer (e.g. pressure and carrier gas velocity) [1]. The aim of this study was to investigate spray drying of some Latvian illite clay and the morphology of obtained clay granules.

\section{MATERIALS AND METHODS}

Clay deposits. Latvian illite clays from Laža, Pavāri and Iecava deposits were investigated. Iecava is Devonian clay that is a byproduct of refining dolomite from deposits in Bauska district, Laža is Quaternary clay deposit in Liepāja district 5 $\mathrm{km}$ to ZA from Aizpute. Pavāri is Devonian clay deposit in Cesvaine district. All deposits are economically feasible for use, they are under thin overburden layer or a byproduct in exploited deposit.

Mineral composition. The mineral composition of these clays has been investigated before [3] by X-ray diffraction and Quanto software, chemical composition was analysed by Scanning electron microscopy and chemical analysis. Fraction under 
$63 \mu \mathrm{m}$ contained following minerals: Iecava $-51 \%$ illite, $11 \%$ quartz, $26 \%$ feldspar, $8 \%$ muscovite, $4 \%$ dolomite; Laža - 34\% illite, $11 \%$ kaolinite, $8 \%$ chlorite, $13 \%$ quartz, $16 \%$ feldspar, $8 \%$ calcite, dolomite 5\% dolomite, 5\% muscovite; Pavāri $35 \%$ illite, $4 \%$ kaolinite, $54 \%$ quartz, $7 \%$ feldspar. Pavāri clay did not contain carbonates that promotes aggregation and increase $\mathrm{pH}$.

Iecava clay is gray, (5Y 7/1 after Munsell color chart), Lažaclay - light brown (7,5YR 6/4), Pavāri clay - pink white $(7,5 \mathrm{YR} 8 / 2)$. All clay contain iron ions, that can be dissolved using acid. [3].

Slurry. Clays were dispersed in distilled water, no additives (e.g. deflocculants) or other chemical treatment was used. Fraction under $2 \mu \mathrm{m}$ was separated by slurry centrifuge. Slurry with clay mass fraction of 7-9 \% was obtained after first centrifugation and 1-2 \% - after second centrifugation. The concentration was measured by evaporative moisture analyzer Kern MRS120-3. Viscosity was analyzed by reometer RheolabQC (Anton Paar) at $200 \mathrm{rpm}$ speed.

Spray drying. Several operational conditions were tested. The criteria for suitable drying conditions were that no moist slurry droplets deposited in the lower part of drying chamber and dried particles reach cyclone and powder collecting chamber.

Slurry concentrations used in spray drying were $\sim 1.5,8,15$ and $20 \%$. Clays were spray dried in laboratory scale dryer - BUCHI Mini Spray Dryer B-290, spray dispersion was obtained in two-fluid nozzle, spray feed was ensured by peristaltic pump, aspirator worked in suction setting, so there was underpressure in the system. The yield of dryer is $50-1000 \mathrm{~mL} / \mathrm{h}$. Operational conditions that varied were inlet temperature (maximal for equipment is $225^{\circ} \mathrm{C}$ ), slurry feed rate, gas pressure. The constant settings were drying time and efficiency of cyclone that is determined by aspirator flow $-80 \%$ of power, fresh air humidity $32-40 \%$ and temperature $18-22{ }^{\circ} \mathrm{C}$. Experimental parameters are shown in table 1.

Sample names. Sample names are made from Clay deposit (Iecava, Laža and Pavāri - Ie, La and $\mathrm{Pa}$ respectively), concentration and drying setting according to table I, e.g. Ie $20 \% 4$ is Iecava clay slurry with a solid mass fraction $20 \%$ dried in $4^{\text {th }}$ setting.

Clay granule analysis. The size and morphology was investigated by high emission field electron microscopy Tescan Mira/LMU and microscopy image analyse software Image PRO. At least 1000 granules were measured for each sample.

The Surface area and porosity was measured by liquid nitrogen $(77 \mathrm{~K})$ absorption in automated analyser QuadraSorb SI. The analysed sample weight was $0.2 \mathrm{~g}$, before sorption it was outgassed at $100{ }^{\circ} \mathrm{C}$ for $24 \mathrm{~h}$.

TABLE I

SPRAY DRYER SETTINGS

\begin{tabular}{|c|c|c|c|}
\hline $\begin{array}{c}\text { Setting } \\
\text { No. }\end{array}$ & $\begin{array}{c}\text { Inlet temperature, } \\
{ }^{\circ} \mathrm{C}\end{array}$ & $\begin{array}{c}\text { Slurry feed pump, } \\
\% / \mathrm{mL} / \mathrm{min}\end{array}$ & $\begin{array}{c}\text { Gas pressure, } \\
\mathrm{mm} / \mathrm{normL} / \mathrm{h}\end{array}$ \\
\hline 1 & 220 & $25 / 6.7$ & $15 / 192$ \\
\hline 4 & 200 & $25 / 6.7$ & $15 / 192$ \\
\hline 5 & 200 & $25 / 6.7$ & $25 / 301$ \\
\hline 6 & 220 & $30 / 8.0$ & $25 / 301$ \\
\hline 7 & 190 & $30 / 8.0$ & $25 / 301$ \\
\hline 8 & 220 & $35 / 9.3$ & $35 / 414$ \\
\hline 9 & 220 & $40 / 10.7$ & $30 / 357$ \\
\hline 10 & 220 & $35 / 9.3$ & $30 / 357$ \\
\hline 11 & 220 & $50 / 13.3$ & $40 / 473$ \\
\hline 12 & 223 & $45 / 12.0$ & $40 / 473$ \\
\hline 13 & 190 & $30 / 8.0$ & $40 / 473$ \\
\hline 14 & 190 & $25 / 6.7$ & $35 / 414$ \\
\hline
\end{tabular}

\section{RESULTS AND DISCUSSION}

Viscosity of slurry. Concentrated clay slurry is non-Newtonian fluid [6]. As it can be seen in Table II the viscosity of clay slurry strongly depends on mixing rate (or shear rate). At the beginning of measurement the viscosity of Ie $15 \%$ at $200 \mathrm{rpm}$ was $15.4 \mathrm{mPa} \cdot \mathrm{s}$, but after $100 \mathrm{~s}$ it stabilized at 13.8 $\mathrm{mPa} \cdot \mathrm{s}$

TABLE II

THE VISCOSITY (mPa.s) OF Ie20\% AFTER MIXING AT CONSTANT RATE FOR 10 MIN

\begin{tabular}{|c|c|c|c|c|}
\hline Repeat & $40 \mathrm{rpm}$ & $60 \mathrm{rpm}$ & $80 \mathrm{rpm}$ & $200 \mathrm{rpm}$ \\
\hline 1 & 189 & 131 & 100 & 22.8 \\
\hline 2 & 182 & 127 & 99.5 & 22.4 \\
\hline
\end{tabular}

The viscosity of all samples was different, the most viscous was Laža clay slurry, and the lest viscous was Pavāri clay slurry (Fig. 1).

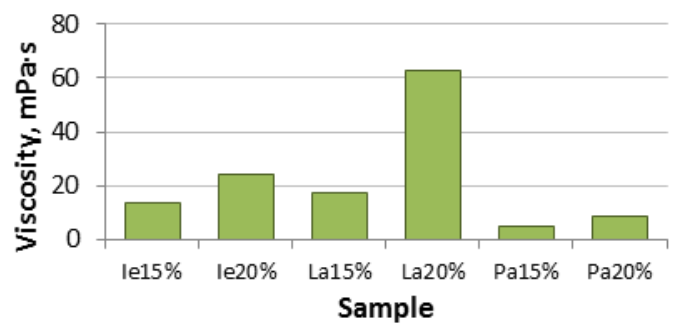

Fig. 1. The viscosity of investigated clay slurries (after $10 \mathrm{~min}$, mixing rate $200 \mathrm{rpm}$ )

The viscosity of La15\% was $17.6 \mathrm{mPa} \cdot \mathrm{s}$ at the beginning of measurement and after 65-115 s stabilized at $17.3 \mathrm{~Pa} \cdot \mathrm{s}$ that is $20 \%$ lower than Ie $15 \%$. The La20\% was 3.6 times higher viscosity than La15\%, 2.7 times higher than Ie20\% viscosity and 7.3 times higher than Pa20\%. First 
measurement of La20\% at the beginning showed the viscosity as high as $0.0873 \mathrm{~Pa} \cdot \mathrm{s}$ and after 10 $\min$ it decreased to $68.6 \mathrm{mPa} \cdot \mathrm{s}$, repeating measurement after few minutes did not showed so rapid decrease of viscosity 68.8 to $65.0 \mathrm{mPa} \cdot \mathrm{s}$ and in next repeating it decreased from 65.3 to 62.8 $\mathrm{mPa} \cdot \mathrm{s}$ (the slopes are shown in Fig. 2).

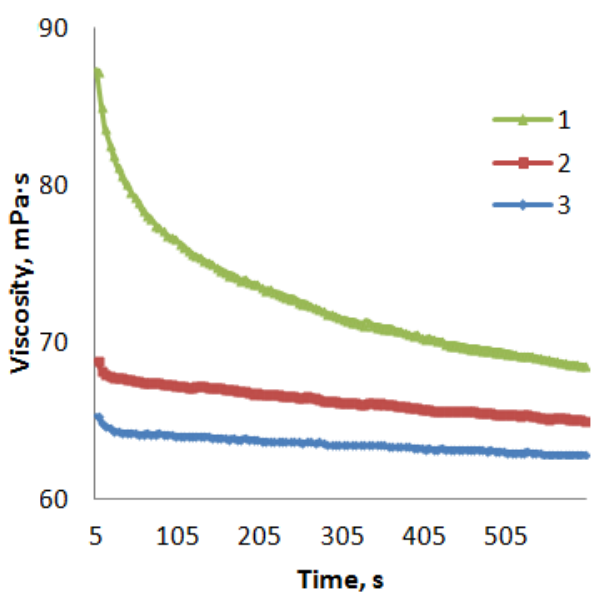

Fig. 2. The change of viscosity in time of La20\% slurry in three following measurements

Other studies have shown that suspensions exhibit a rapid increase of apparent viscosity, if solid concentration (fraction $<63 \mu \mathrm{m}$ ) is raised from 30 to $35 \mathrm{wt} \%[6]$.

To ensure the homogeneity and lower viscosity in slurry feed tube of spray drier, the slurry is intensively mixed on magnetic mixer before feed.

The effect of concentration and viscosity on spray dried particle surface area and size. Surface area dependence on slurry concentration was observed for more viscous Laža slurry: La20\% had the smallest average surface area $71 \mathrm{~m}^{2} / \mathrm{g}, \mathrm{La} 15 \%$ 74 and $\mathrm{La} 8 \%$ - $76 \mathrm{~m}^{2} / \mathrm{g}$. Surface area was practically not affected by settings of spray drier for La20\%. For less viscous slurry La15\% and La8\% the impact of feed rate and nozzle gas velocity increased. La8\%_13 surface area was $75 \mathrm{~m}^{2} / \mathrm{g}$ while La8\% average surface area was $77 \mathrm{~m}^{2} / \mathrm{g}$.

All Iecava and Pavāri samples showed significantly larger surface area, the average surface area of Iecava samples was $92 \mathrm{~m}^{2} / \mathrm{g}$ (StandardDeviation 2), Pavāri - $89 \mathrm{~m}^{2} / \mathrm{g}$ (StDev 3) while Laža - only $74 \mathrm{~m}^{2} / \mathrm{g}$ (StDev 2). For Iecava and Pavāri samples definite relationship between the investigated spray dryer parameters and surface area of granules was not found (Fig. 3).

The role of inlet temperature. Inlet temperature in a range of $190-220{ }^{\circ} \mathrm{C}$ was found to be appropriate to produce dry clay granules (moisture content 3-10 wt\%). The outlet temperature was 70 $96{ }^{\circ} \mathrm{C}$. For the inlet temperature as low as $190{ }^{\circ} \mathrm{C}$ maximal slurry feed rate was $30 \%$ or $8 \mathrm{~mL} / \mathrm{min}$ to achieve dry sample.

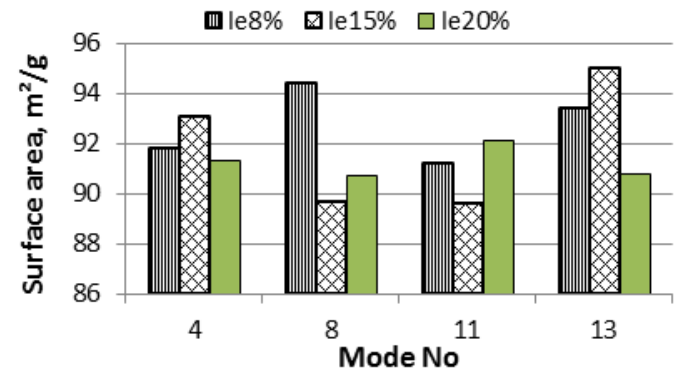

Fig. 3. Surface area of Iecava clay granules obtained from slurries with various concentrations and spray dried at various settings.

Sorption isotherms and porosity. The sorption isotherm of all samples was between Type II and type IV isotherms (Fig. 4) after IUPAC classification; that corresponds to "high surface energy solids" [7]. Type II isotherms typically characterise non-porous or macroporous materials. Other authors have obtained similar sorption data of natural illite clay [5].

The inflection point or knee of the isotherm (called point B) that indicates the stage at which monolayer coverage is complete and multilayer adsorption begins to occur was detected at relative pressure $\mathrm{p} / \mathrm{p}_{0}$ was less than 0.04 for all samples. The absorbed volume at $\mathrm{p} / \mathrm{p}_{0} 0.04$ was $18 \mathrm{~cm}^{3} / \mathrm{g}$.

The obtained clay granules mostly contain macropores $(>50 \mathrm{~nm})$ as the adsorption isotherm rose rapidly near $\mathrm{p} / \mathrm{p}_{0}=1$ and in the limit of large macropores exhibit an essentially vertical rise.

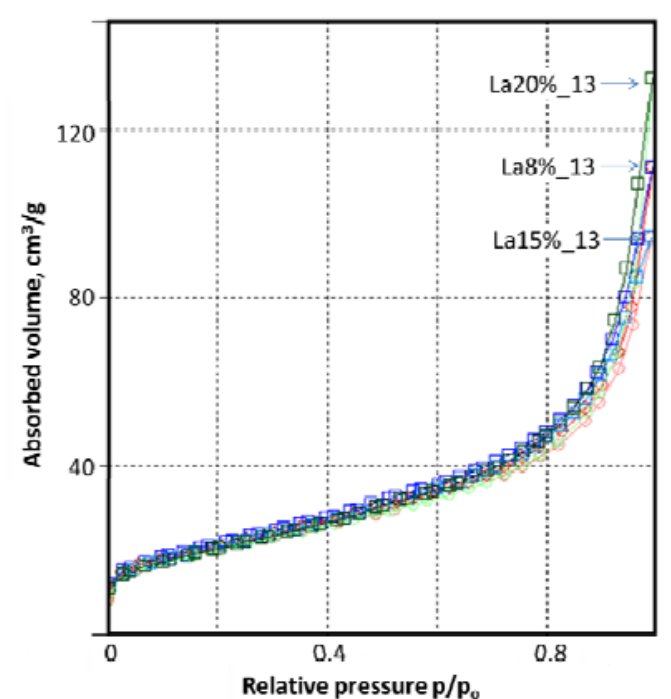

Fig. 4. Adsorption-desorption isotherms of nitrogen on some Laža clay granules.

A narrow hysteresis loop that is characteric mesopores (pore diameter 2-50 nm) was observed (Fig. 5). The size and shape of hysteresis loop was similar within the same clay type irrespective to spray drying conditions, but slightly differed for 
each clay deposit. This can be due to flocculation of clay particles.

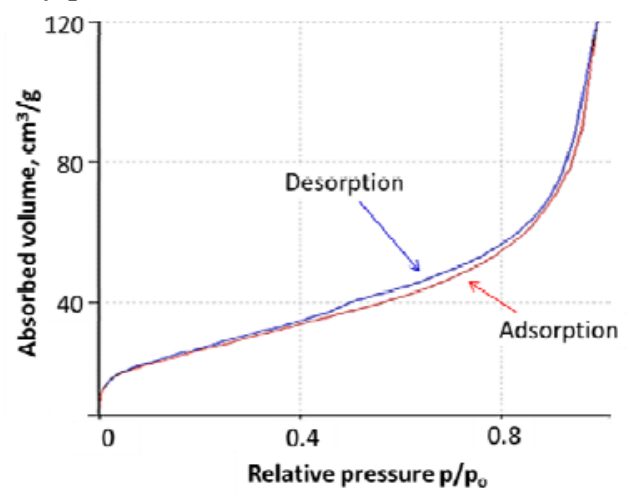

Fig. 5. Hysteresis loop of adsorption isotherms on Pavāri clay granules.

Total pore volume for pores with radius less than $83.8 \mathrm{~nm}$ at $\mathrm{p} / \mathrm{p}_{0}=0.988418$ was greater for less viscous samples: Ie $8 \%$ - average is $0.3 \mathrm{~cm}^{3} / \mathrm{g}$, more viscous Ie $20 \%$ is around 0.2 and all Laža samples fit in range $0.1-0.2$. The porosity and pore size depends on median diameter of primary particles, solid mass concentration and flocculation state; it does not depend on ambient air and initial droplet volume [8]. In studied case it can be concluded that porosity of clay granules is determined by mineral composition, e.g. impurities like iron containing minerals that increase flocculation of clay minerals.

Size and shape of granules. The size of granules varied from operational conditions (Fig. 6.). The largest granules were obtained in setting of drying No 4 that had lowest air flow and slurry feed rate, for Ie15\% 4 size reached $5.2 \mu \mathrm{m}$ (StDev 4.1) and the smallest was for $\mathrm{La} 8 \% 8$ and $\mathrm{La} 8 \% 13-2.6$ $\mu \mathrm{m}$ (StDev 1.4). The mean diameter of granules correlate with maximal diameter, the correlation coefficient was 0.992 . The size distribution was similar for all samples (Fig. 7 and Fig. 8a and 8b).

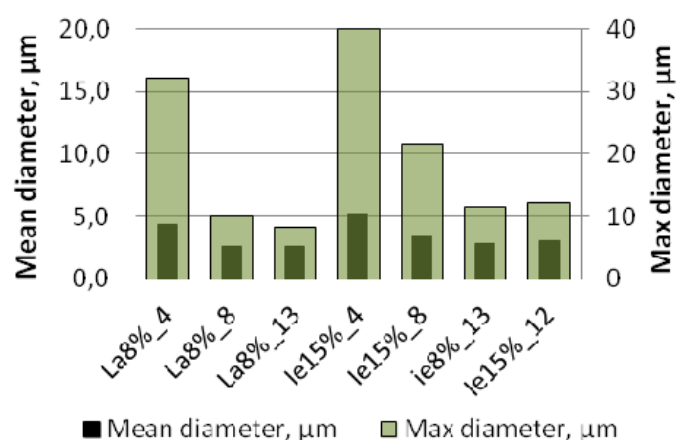

Fig. 6. The size of spray dried granules. Different clay types dried in various conditions.

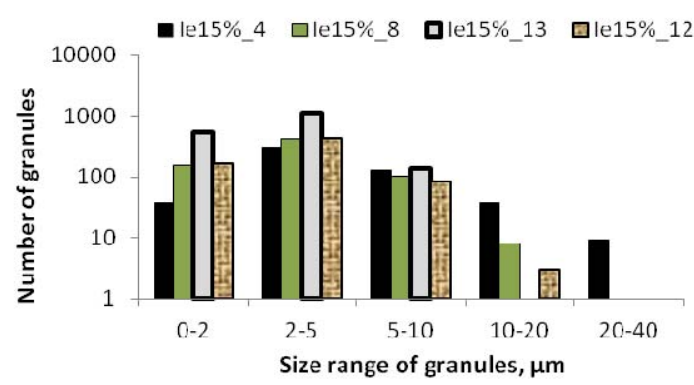

Fig. 7. The size distribution of granules. Iecava clay $15 \%$ slurry dried in different conditions.

All obtained granules were dense without large macropores or holes (Fig. 8), however the surface was rough. Most of granules were well-rounded, but not all was ideally spherical. The size and shape of granules were similar irrespective of clay type or concentration or spray dryer settings (Fig. 8c, 8d and 8e). Plate-like surface structure can be seen especially for Iecava clay granules (Fig. 8c), however the plates are not a single clay particles (Fig. 8f).

a) $\mathrm{Pa} 20 \% \_4$

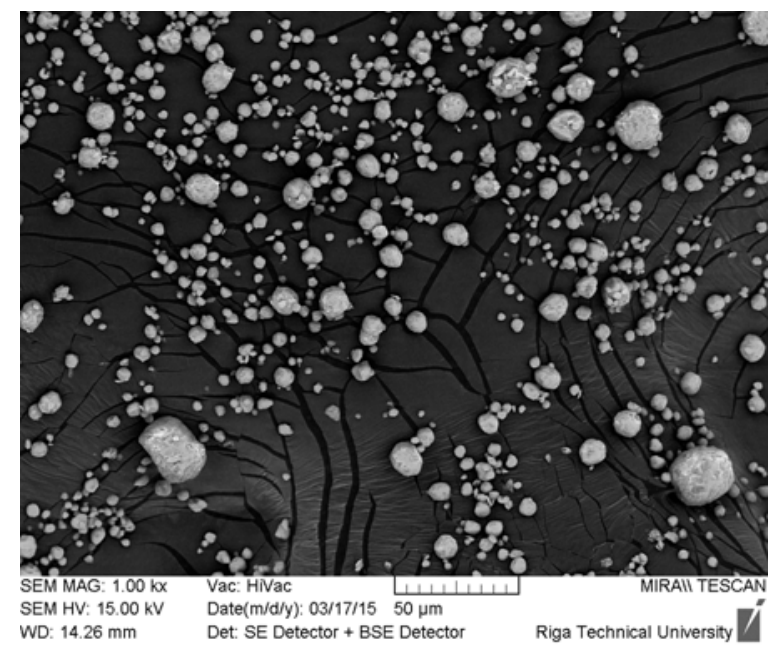


b) La15\%_4

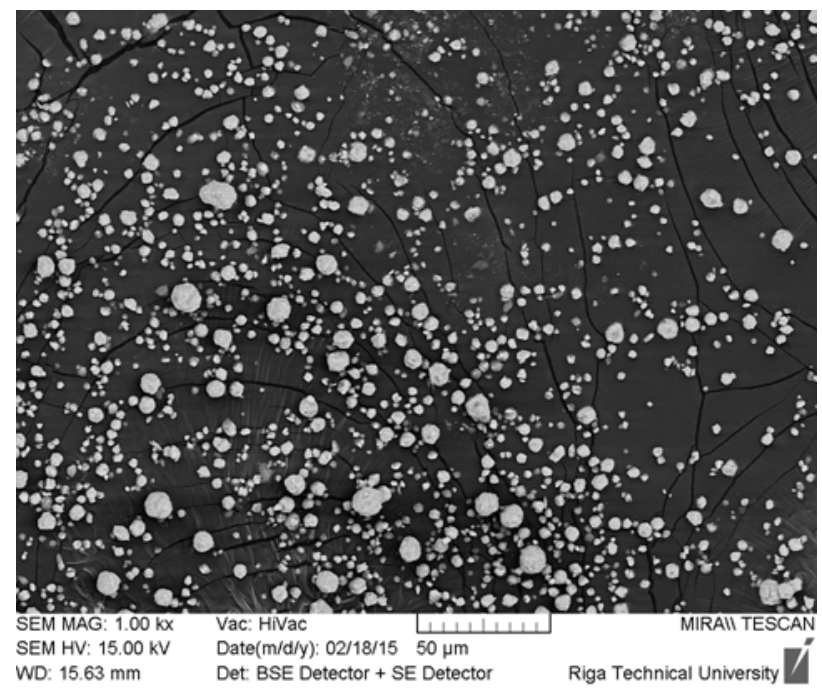

c) Ie15\%_14

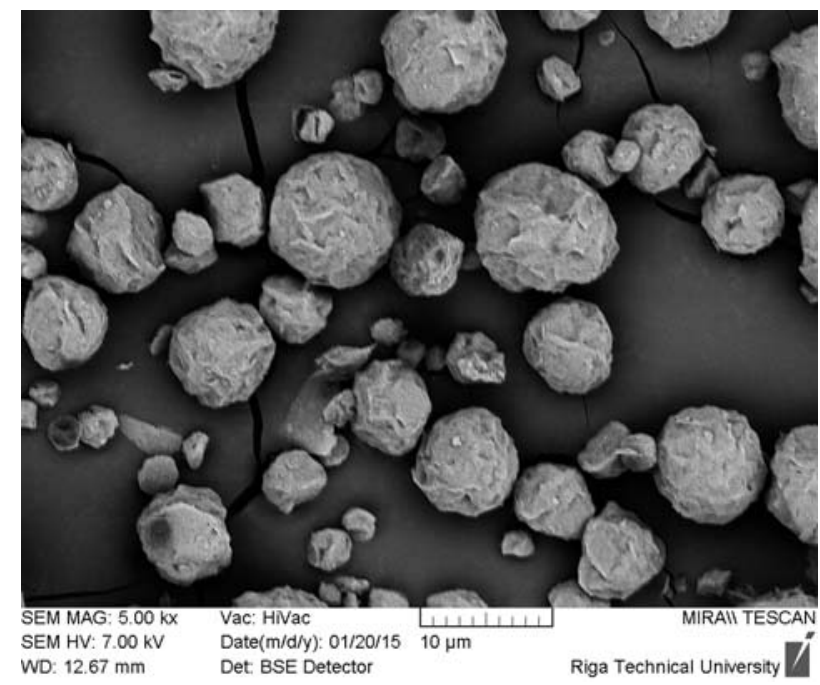

d) La15\%_14

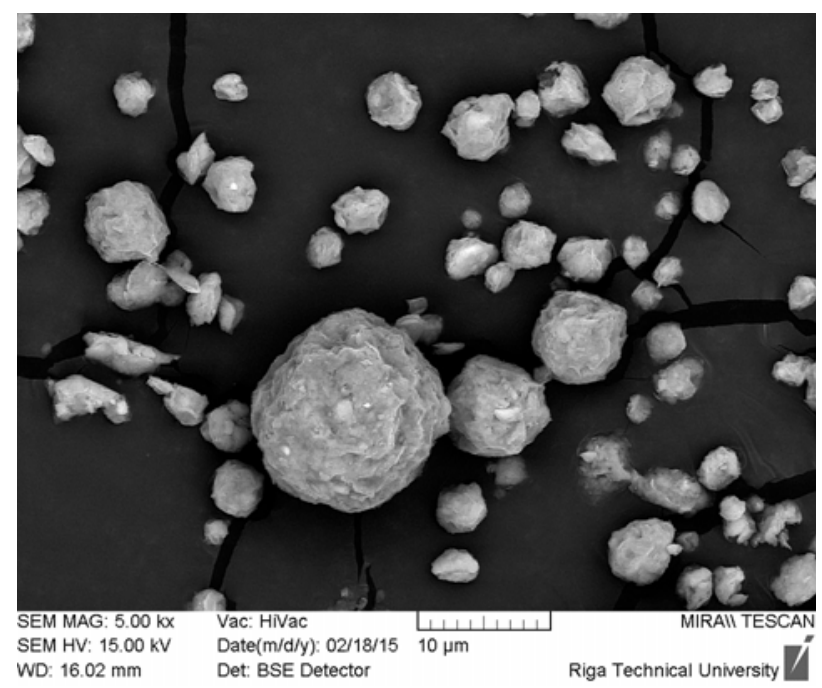


e) Pa15\%_14

f) $\mathrm{Pa} 15 \% \_14$
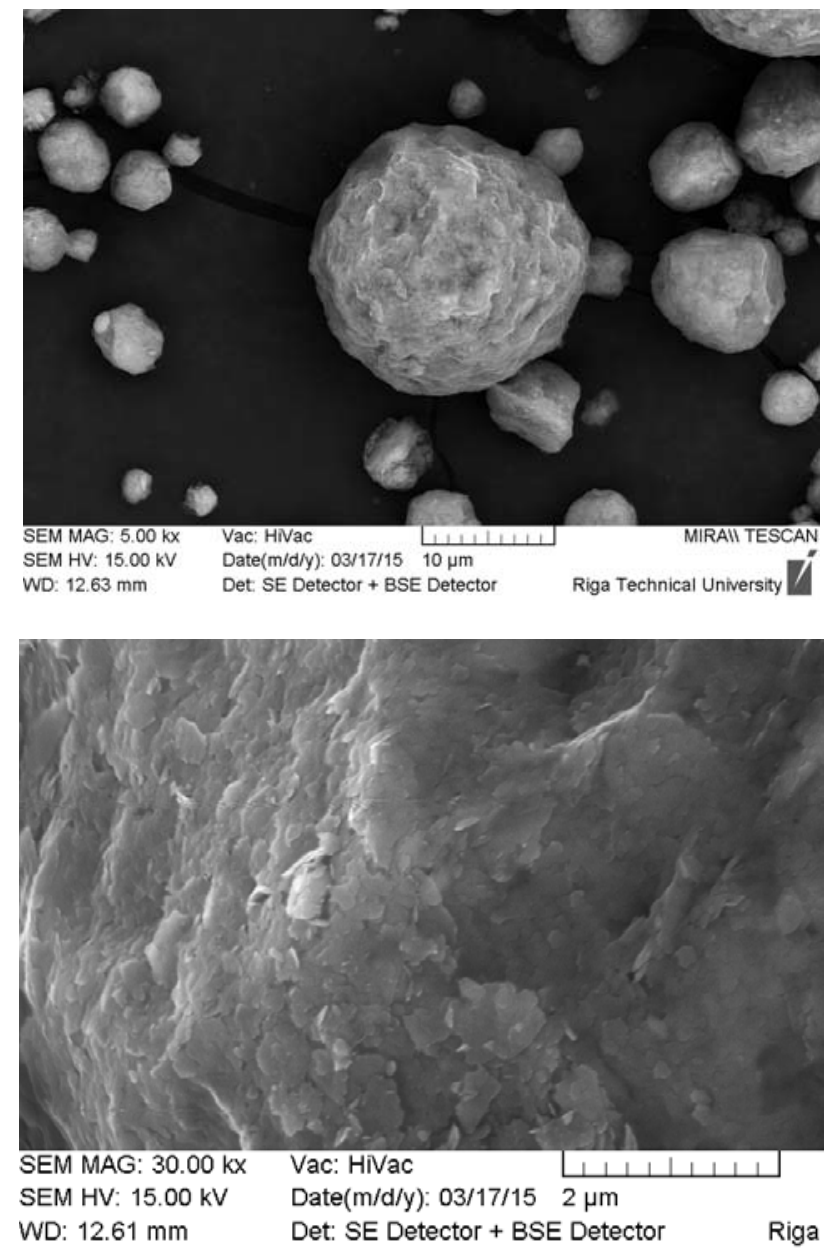

Fig. 7. Clay granules, SEM images

\section{CONCLUSIONS}

The morphology of clay granules are not sensitive to operational conditions of spray dryer. The surface area depends mostly of clay composition while the mean diameter is significantly affected by slurry feed rate and air flow. The mean diameter of granules was 2.6. Inlet temperature in a range of $190-220^{\circ} \mathrm{C}$ was found to be appropriate to produce well dried clay granules (moisture content $<10 \mathrm{wt} \%$ ). All obtained spray dried samples had well-rounded granules.

\section{$\mathrm{V}$ ACKNOWLEDGMENTS}

This work has been supported by the National Research Program of Latvia 2014-2017 within the project No.4.4. (Y8099) „Zemes dzịlu resursu izpēte dabisko izejvielu dažāošanai un jaunu tehnologiju izstrādei (GEO)" (Investigation of underground resources to obtain different natural raw materials and to develop new technologies (GEO)).

\section{REFERENCES}

[1] A. B. D. Nandiyanto and K. Okuyama, "Progress in developing spray-drying methods for the production of controlled morphology particles: From the nanometer to submicrometer size ranges," Adv. Powder Technol., vol. 22, no. 1, pp. 1-19, Jan. 2011.

[2] R. Hughes and B. Bohor, "Random clay powders prepared by spray-drying," Am. Mineral., vol. 55, pp. 1780-1786, 1970 .

[3] I. Dušenkova, "Latvijas mālu sagatavošanas tehnologijas izstrāde un īpašību pētījumi izmantošanai kosmētiskajos produktos," Rīgas Tehniskā universitāte, 2014.

[4] V. Lakevičs, V. Stepanova, I. Skuja, I. Dušenkova, and A. Ruplis, "Influence of Alkali and Acidic Treatment on Sorption Properties of Latvian Illite Clays," Key Eng. Mater., vol. 604, pp. 71-74, Mar. 2014.

[5] R. a. Alvarez-Puebla, D. S. Dos Santos, C. Blanco, J. C. Echeverria, and J. J. Garrido, "Particle and surface characterization of a natural illite and study of its copper retention," J. Colloid Interface Sci., vol. 285, pp. 41-49, 2005. 
[6] I. Dusenkova, "Rheological properties of Latvian illite clays," Acta Geodyn. Geomater., vol. 10, no. 4, pp. 459464, Nov. 2013.

[7] F. Wypych and K. G. Satyanarayana, Eds., Clay Surfaces. Fundamentals and Applications. London: Elsevier Academic Press, 2004, p. 567.
[8] R. Mondragon, J. C. Jarque, J. E. Julia, L. Hernandez, and A. Barba, "Effect of slurry properties and operational conditions on the structure and properties of porcelain tile granules dried in an acoustic levitator," J. Eur. Ceram. Soc., vol. 32, no. 1, pp. 59-70, Jan. 2012. 